\title{
Impact of single-gene and dual-gene Bt broccoli on the herbivore Pieris rapae (Lepidoptera: Pieridae) and its pupal endoparasitoid Pteromalus puparum (Hymenoptera: Pteromalidae)
}

\author{
Mao Chen · Jian-zhou Zhao • \\ Anthony M. Shelton · Jun Cao • \\ Elizabeth D. Earle
}

Received: 21 March 2007 / Accepted: 31 July 2007 / Published online: 13 September 2007

(C) Springer Science+Business Media B.V. 2007

\begin{abstract}
Transgenic brassica crops producing insecticidal proteins from Bacillus thuringiensis (Bt) are being investigated as candidates for field release to control lepidopteran pests. Information on the potential impact of Bt brassica crops on pests and non-target natural enemies is needed as part of an environmental risk assessment prior to the commercial release. This first tier study provides insight into the tritrophic interactions among Bt broccoli plants, the herbivore Pieris rapae and its parasitoid Pteromalus puparum. We first evaluated the efficacy of three types of $\mathrm{Bt}$ broccoli plants, crylAc, crylC and crylAc + crylC, on different instars of $P$. rapae. Bt broccoli effectively controlled $P$. rapae larvae, although later instars were more tolerant. The efficacy of different Bt broccoli plants on $P$. rapae larvae was consistently crylAc $>$ crylAc + cry $l C>$ crylC. When the parasitoid $P$. puparum developed in a $P$. rapae pupa (host) that had developed from Bt plant-fed older larvae, developmental time, total number and longevity of the $P$. puparum generated from the Bt plant-fed host were significantly affected compared with those generated from the non-Bt control plant-fed host.
\end{abstract}

M. Chen · J.-z. Zhao · A. M. Shelton ( $\square)$

Department of Entomology, NYSAES,

Cornell University, Geneva, NY 14456, USA

e-mail: ams5@cornell.edu

J. Cao $\cdot$ E. D. Earle

Department of Plant Breeding \& Genetics,

Cornell University, Ithaca, NY 14853, USA
Simultaneously, negative effects on $P$. rapae pupae were found, i.e. pupal length, width and weight were significantly reduced after older $P$. rapae larvae fed on different Bt plants for 1 or 2 days. Cry $1 \mathrm{C}$ toxin was detected using ELISA in $P$. rapae pupae after older larvae fed on crylC broccoli. However, no Cry1C toxin was detected in newly emerged $P$. puparum adults developing in Bt-fed hosts. Only a trace amount of toxin was detected from entire $P$. puparum pupae dissected from the Bt plant-fed host. Moreover, no negative effect was found on the progeny of $P$. puparum developing from the Bt plant-fed host when subsequently supplied with a healthy host, $P$. rapae pupae. The reduced quality of the host appears to be the only reason for the observed deleterious effects on $P$. puparum. Our data suggest that the effects on $P$. puparum developing in Bt plant-fed $P$. rapae are mediated by host quality rather than by direct toxicity.

Keywords Bacillus thuringiensis .

Pieris rapae - Pteromalus puparum .

Transgenic broccoli $\cdot$ Tritrophic interactions

\section{Introduction}

Lepidopteran pests of brassica vegetables, such as diamondback moth, Plutella xylostella L. (Lepidoptera: Plutellidae) and imported cabbageworm, Pieris rapae L. (Lepidoptera: Pieridae), are severe economic threats to production. Moreover, the lack of a 
diversity of strategies for managing lepidopteran pests has resulted in an almost total dependence on traditional synthetic insecticides that can cause negative impacts on non-target parasitoids and predators, and the rapid development of insecticide resistance (Shelton et al. 1993; Vásquez et al. 1997; WoldBurkness et al. 2005). The development of plants expressing Bacillus thuringiensis (Bt) insecticidal crystal proteins (Cry toxins) offers an alternative strategy to control insect pests (Shelton et al. 2002b). Among the first commercialized transgenic crops containing Bt insecticidal proteins were Bt maize and Bt cotton, which were protected from attack by lepidopteran pests (i.e. corn borers in maize and the budworm-bollworm complex in cotton) (Shelton et al. 2002b). Bt plants were grown on 32.1 million ha worldwide in 2006 (James 2006). These crops have readily been adopted by farmers in a number of countries and have provided economic benefits to growers and reduced the use of insecticides (Shelton et al. 2002b; Brookes and Barfoot 2006; James 2006). Advances in insect-resistant transgenic crops in recent years have also offered a promising alternative to traditional synthetic insecticides for controlling lepidopteran pests in brassica vegetables. Previous studies in our and other laboratories have shown that $P$. xylostella can be controlled well using Brassica oleracea L. plants carrying a synthetic or fully modified Bt gene (Metz et al. 1995; Cao et al. 1999; Jin et al. 2000; Bhattacharya et al. 2002). Additional studies with a crylC gene expressed in broccoli demonstrated that these transgenic plants are able to control Cry1Ac-resistant P. xylostella (Cao et al. 1999), and studies with pyramided crylAc and crylC broccoli plants demonstrated that these plants have excellent control of both Cry1C-resistant and Cry1Ac-resistant P. xylostella (Cao et al. 2002). Similarly, transgenic collards with crylAc or crylC genes showed complete control of susceptible $P$. $x y$ lostella larvae (Cao et al. 2005). It is noteworthy that both crylC broccoli and Chinese cabbage have been reported to provide promising control of $P$. rapae and Trichoplusia ni Hübner (Lepidoptera: Noctuidae) neonate larvae (Cao et al. 1999; Cho et al. 2001).

A major concern regarding the utilization of $\mathrm{Bt}$ plants is their potential impact on non-target organisms (Romeis et al. 2006). As part of an ecological risk assessment before commercial release, it is crucial to evaluate the efficacy of Bt crops on target lepidopteran pests as well as their potential impact on non-target natural enemies. In the case of brassica vegetables, all of the work carried out to date has been conducted against lepidopteran pests, as cited above, with some additional studies conducted against one of their parasitoids (Schuler et al. 2004). However, there is as yet no report on the efficacy of Bt broccoli on different instars of $P$. rapae, except for neonates (Cao et al. 1999; Cho et al. 2001), nor on its impact on the non-target natural enemies of $P$. rapae. Negative impacts of $\mathrm{Bt}$ toxins on non-target parasitoids have been reported in tritrophic studies with Bt transgenic plants and susceptible herbivores that were fed with $\mathrm{Bt}$ plant tissue (Bernal et al. 2002; Baur and Boethel 2003; Meissle et al. 2004; Prütz and Dettner 2004). In general, parasitoids are very sensitive to changes in their hosts due to toxin ingestion, since the parasitoids usually complete their development in a single host. When Bt-susceptible hosts are treated with Bt toxins, their parasitoids are likely to be affected more than predators, which are often generalists and feed on several different prey species (Salama and Zaki 1983).

Pteromalus puparum L. (Hymenoptera: Pteromalidae) is a pupal endoparasitoid of P. rapae. $P$. puparum may lay up to 700 eggs in her lifespan and $>200$ offspring can be produced from a single pupa of $P$. rapae (Mahr 1996). A long-term survey in New York indicated that $44.4 \%$ of pupae of $P$. rapae were parasitized by $P$. puparum (Shelton et al. 2002a), while a study in Minnesota documented that $P$. puparum was the dominant parasitoid species of $P$. rapae with a maximum parasitism rate of $31 \%$ that effectively reduced insect pest pressure under field conditions (Wold-Burkness et al. 2005).

In order to evaluate the potential use of $\mathrm{Bt}$ vegetables, we investigated the efficacy of $\mathrm{Bt}$ broccoli plants with crylAc or crylC single genes, or with the combination of the two genes (pyramided genes), on $P$. rapae larvae at different stages and the potential impact on the parasitoid, $P$. puparum, via the $P$. rapae host. The experiments were designed to address the following questions:

(1) Does the efficacy of single- and dual-gene $\mathrm{Bt}$ broccoli vary according to the different life stages of $P$. rapae larvae?

(2) Will $P$. puparum adults be adversely affected when developing in single-gene and dual-gene Bt broccoli-fed $P$. rapae? 
(3) Does the $\mathrm{Bt}$ toxin transfer through different trophic levels in the $P$. rapae- $P$. puparum system? If so, can it be quantified?

\section{Materials and methods}

Bt broccoli plants

Three types of transgenic broccoli (Brassica oleracea L., var. italica' Green Comet) plants producing high levels of Cry1Ac $(0.63 \mu \mathrm{g} / \mathrm{g}$ fresh leaf tissue), Cry $1 \mathrm{C}$ $(1.12 \mu \mathrm{g} / \mathrm{g}$ fresh leaf tissue) or both (Cry1Ac: 0.69$0.72 \mu \mathrm{g} / \mathrm{g}$ fresh leaf tissue; Cry1C: $0.27-1.23 \mu \mathrm{g} / \mathrm{g}$ fresh leaf tissue) and non-transgenic broccoli (control) were used in this study (Metz et al. 1995; Cao et al. 1999, 2002). The progenies of crylAc- and crylC-expressing plants were verified by screening them with Cry1C-resistant (Cry1C-R) and Cry1Acresistant (Cry1Ac-R) Plutella xylostella neonates, respectively, when the plants were 4-5 weeks old (Tang et al. 2001). Both crylAc and crylC plants also killed $100 \%$ of the neonates of the $F_{1}$ heterozygotes (susceptible strain of $P$. xylostella $(\mathrm{S}) \times$ Cry1Ac-R) or $100 \%$ of all instars of the $F_{1}$ heterozygotes $(\mathrm{S} \times$ Cry1C-R), respectively (Zhao et al. 2002), indicating that the plants expressed a high dose for the purpose of resistance management (US EPA 2001). Broccoli plants that expressed both the crylAc and $c r y l C$ genes were produced by sexual crosses between the two types of $\mathrm{Bt}$ broccoli and were characterized for $\mathrm{Bt}$ protein production and the control of S, Cry1Ac-R and Cry1C-R P. xylostella strains (Cao et al. 2002). Enzyme-linked immunosorbant assay (ELISA) analysis showed that Cry1Ac and Cry $1 \mathrm{C}$ toxins were produced in the hybrids and in their $F_{1}$ progeny (Cry1Ac: $0.62-0.68 \mu \mathrm{g} / \mathrm{g}$ fresh leaf tissue; Cry1C: $0.94-1.38 \mu \mathrm{g} / \mathrm{g}$ fresh leaf tissue) at levels comparable to those in the original single-gene parental lines (Cao et al. 2002).

Insects

Pieris rapae adults and pupae were collected from the Fruit and Vegetable Research Farm of Cornell University's New York State Agricultural Experiment Station (Geneva, NY) in July, 2005 and continuously raised in a rearing chamber under the conditions of $27^{\circ} \mathrm{C}$, a relative humidity (RH) of 75$80 \%$ and a photoperiod of 16:8 h (light:dark) based on the methods of Webb and Shelton (1988).

A starting population of the pupal endoparasitoid Pteromalus puparum was obtained from Pieris rapae pupae collected from the farm in September 2005 that had been naturally parasitized under field conditions. The field-collected $P$. rapae pupae were returned to the laboratory and placed in a wood-framed cage with netting sides $(50 \times 50 \times 50 \mathrm{~cm})$. After emergence, 20 pairs of $P$. puparum adults were moved from the wood-framed cage by mouth aspiration to a Plexiglas cylinder cage supplied with $10 \%$ sugar water, where random mating occurred for $2 \mathrm{~h}$. The mated $P$. puparum adults were released to another wood-framed cage containing $40 \mathrm{P}$. rapae pupae (1-2 days old) collected from our insect culture. After the $P$. rapae pupae were inoculated with $P$. puparum adults for $48 \mathrm{~h}$, they were transferred to a new woodframed cage in a rearing chamber until emergence. The whole adult stage of $P$. puparum was supplied with $10 \%$ sugar water. The rearing work and experiments were carried out in the rearing chamber, except as noted below.

Effects of single-gene and dual-gene Bt broccoli on the herbivore Pieris rapae

\section{Survival of first instar and later instars}

To evaluate the efficacy of different Bt broccoli plants on first instar P. rapae, 50 first instars (2-2.5 days after hatching) were individually kept in 30-ml plastic cups (Wincup, Phoenix, AZ) with a punctured lid to allow ventilation. With 5 first instars as one replication, ten replications were set up for each type of $\mathrm{Bt}$ broccoli plants, i.e. crylAc, crylC and crylAc + crylC, and the non-Bt broccoli plants (control). Larvae were fed with Bt or non-Bt broccoli leaves (5-6 weeks old) and checked daily until pupation or death; the number of dead larvae in each group was recorded and the broccoli leaves were changed if needed. The efficacy of different $\mathrm{Bt}$ broccoli plants on second instar (4-6 days after hatching), third instar (6-8 days after hatching), fourth instar (8-10 days after hatching) and fifth instar (10-12 days after hatching) P. rapae was also 
evaluated through the entire larval stage. The experimental design and conditions were the same as described above.

Sublethal effects on Pieris rapae pupae developing from the fourth to fifth instars fed with Bt broccoli

Based on the effects of different Bt broccoli plants on fourth and fifth instar $P$. rapae after 2 days of feeding, fourth to fifth instar $P$. rapae (9-11 days after hatching) were collected from the insect culture and fed crylAc broccoli plants leaves for 1 or 2 days, then transferred to non-Bt control broccoli plants and reared until pupation. A total of 50 pupae (1-2 days old) were randomly collected from the 1- to 2-day feeding treatments and divided into ten groups (replications) of five pupae in each. The length, width and weight of the pupae in each group from different treatments were measured and recorded. The same treatments were used for crylC and crylAc + crylC broccoli plants. Pupae used as controls were developed from non-Bt broccoli-fed fourth to fifth instar $P$. rapae larvae, and their characteristics were compared with those of pupae developed from larvae fed with crylAc, crylC or crylAc + crylC broccoli for 1 and 2 days.

Effects of single-gene and dual-gene Bt broccoli on the parasitoid Pteromalus puparum

\section{Effects on parasitism, developmental time, proportion of females and longevity of $\mathrm{P}$. puparum}

After $P$. rapae pupae (1-2 days old) were evaluated for sublethal effects as described above, the pupae were submitted to $P$. puparum adults collected from our insect culture to assess the impact of single-gene and dual-gene Bt broccoli on the parasitoid. A total of 25 pupae from each type of broccoli plant (Bt and non-Bt) were individually placed into $30-\mathrm{ml}$ plastic cups and divided into five groups (replications) with five pupae in each. Newly emerged $P$. puparum adults $(<1.5$ days $)$ were transferred into a woodframed cage using an aspirator (female: male 1:1) and allowed to mate randomly for $2 \mathrm{~h}$. Each Pieris rapae pupa was inoculated with one pair of $P$. puparum adults for $48 \mathrm{~h}$ in a cylinder cage. The parasitized pupa was kept in a Plexiglas cylinder. The developmental time of $P$. puparum (from oviposition to adult emergence) in the $P$. rapae pupa was recorded. Once $P$. puparum adults had emerged from the pupa, they were supplied with $10 \%$ sugar water. The longevity of $P$. puparum and the proportion of females in each group were recorded and compared with the control group developing from non-Bt broccoli-fed $P$. rapae.

Effects on the progeny of Pteromalus puparum developing from Bt broccoli-fed Pieris rapae

In order to evaluate whether Bt broccoli plants would negatively affect the ability of the progeny of $P$. puparum to utilize a subsequently provided host, the parasitoid adults from $P$. rapae pupae that had developed from larvae fed on different $\mathrm{Bt}$ broccoli plants for 1-2 days were allowed to parasitize $P$. rapae pupae that had not been exposed to $\mathrm{Bt}$ plants (conventional P. rapae pupae). P. puparum adults collected from our insect culture were used as the control. A total of 25 pairs each of $P$. puparum adults that had developed from crylAc, crylC and crylAc + crylC broccoli plant-fed $P$. rapae, respectively, were allowed to parasitize 25 conventional $P$. rapae pupae after randomly mating for $2 \mathrm{~h}$ in a wood-framed cage. The experimental design and conditions were the same as above. Parasitism rate, developmental time, proportion of females and longevity of $P$. puparum adults emerging from the treatment groups were recorded and compared with those from the control.

Transfer of Cry1C toxin through different trophic levels

The food chain comprising crylC broccoli, Pieris rapae and Pteromalus puparum was selected to examine whether Cry1C toxin can be transferred through the different trophic levels and accumulate in P. rapae, because $P$. rapae later instars are relatively more tolerant to cry $1 C$ broccoli (while the impact of different Bt broccoli plants on $P$. puparum was similar).

A total of five new $P$. rapae pupae (from the fourth to fifth instars fed with crylC plants for 1, 2 and 3 days, respectively) were sampled and kept in Eppendorf vials 
$(1.5 \mathrm{ml})$ to detect the transfer and accumulation (if any) of Cry 1C toxin in P. rapae. Each vial contained one pupa as one replication, and there were five replicates per treatment and 15 insects for the study.

Pieris rapae pupae developing from cry $1 \mathrm{C}$ broccolifed fourth and fifth instars for 1-2 days were inoculated by $P$. puparum adults from the culture and kept in the chamber. $P$. puparum pupae were dissected from the parasitized $P$. rapae pupa 7-9 days after inoculation (without damaging the pupae) and washed five times in Wash Buffer (supplied in the Cry1C ELISA kit; EnviroLogix, Catalog no. AP 007, Portland, Me.). The pupae were then dried on a paper towel for $2 \mathrm{~min}$ and put into an Eppendorf vial (all pupae from one host) to detect the presence of Cry1C toxin. In addition, $20 P$. puparum adults were collected following their emergence from the parasitized pupae, chilled at $-20^{\circ} \mathrm{C}$ for $20 \mathrm{~min}$ and placed into a vial. Toxins from cry $\mathrm{lC}$ broccoli and non-Bt broccoli plants (6-7 weeks old) were extracted from 8-mm leaf discs to serve as controls. All samples were weighed and sealed in tubes, with five replications, and then stored at $-20^{\circ} \mathrm{C}$ until the ELISA assays were conducted.

Detection and quantification of the amount of Cry1C toxins in all the samples were monitored by ELISA using the Cry1C kit from EnviroLogix. To extract soluble proteins, each sample was ground and homogenized in $0.5 \mathrm{ml}$ Extraction/Dilution buffer (EnviroLogix). ELISA was conducted according to the manufacturer's instructions. Based on preliminary tests, sample extracts were used at a dilution of 1:51 for cry $1 C$ broccoli and 1:4 for $P$. rapae pupae. The optical density (OD) value of samples was measured using a microplate reader set at $450 \mathrm{~nm}$, with $630 \mathrm{~nm}$ as the reference wavelength. Corresponding tissue blanks (control samples) were subtracted from Bt samples to eliminate any unspecific binding effects of proteins to ELISA test wells. The amount of Cry1C toxins in samples was calculated from standard concentrations obtained with Cry1C (Envirologix) and expressed as micrograms Bt protein/g fresh weight.

\section{Statistical analysis}

Survival analyses of different instar Pieris rapae on Bt broccoli and the non-Bt control were conducted using the Kaplan-Meier procedure and Logrank Test (Norusis 2005). Survival data were recorded until all
$P$. rapae larvae fed with Bt plants were either dead or had pupated. All pupated individuals were recorded as survivors. Data on P. rapae pupae (length, width and weight) and Pteromalus puparum (parasitism rate, developmental time, total number of $P$. puparum, proportion of females and longevity) between plant types ( $\mathrm{Bt}$ and non-Bt) and feeding time treatments were analyzed by two-way ANOVA and Fisher's protected LSD means separation test. Differences in the impact of Bt plants on the progeny of $P$. puparum developing from Bt plant-fed $P$. rapae pupae were analyzed by one-way ANOVA. All percentage data were transformed using arcsine square root before statistical analyses. All statistical analyses were conducted using SPSS FOR WINDOwS ver. 11.5 (SPSS, Chicago, IL).

\section{Results}

Effects of Bt broccoli plants on Pieris rapae

Survival of $\mathrm{P}$. rapae larvae

The survival probability of $P$. rapae larvae was significantly affected by being exposed to Bt broccoli plants from the first instar compared with those exposed to non-Bt control plants $\left(\chi^{2}=171.17, \mathrm{df}=3\right.$, $P<0.001$ ) (Fig. 1). All larvae died within 3 days of

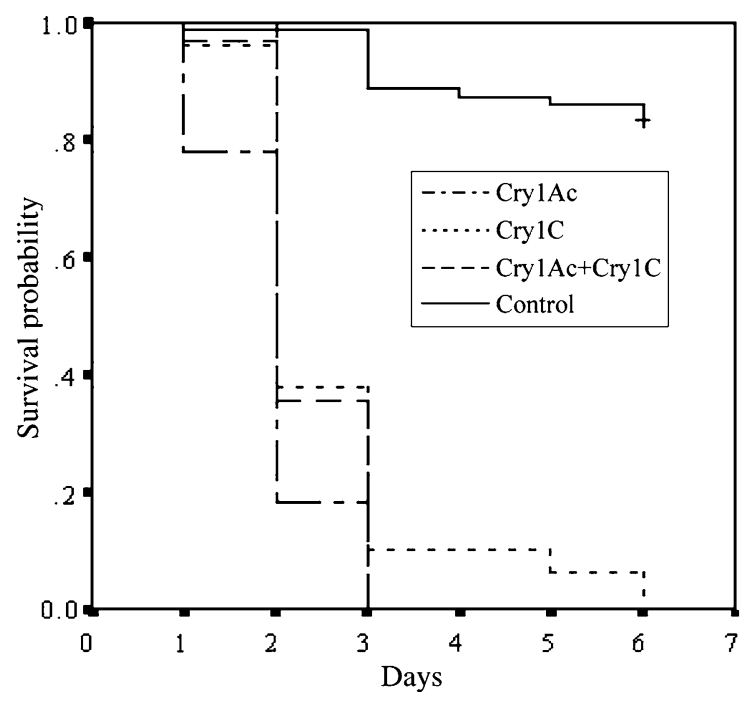

Fig. 1 Survival of Pieris rapae larvae after being fed Bacillus thuringiensis $(\mathrm{Bt})$ broccoli plants and non-Bt control plants from first instar until pupation 
feeding on crylAc or crylAc + crylC broccoli plants and within 6 days of feeding on cry $l C$ plants. Survival probabilities of $P$. rapae larvae were also significantly reduced when they were fed on Bt broccoli plants from the second, third, fourth and fifth instars compared with those fed on the non-Bt control (respectively, $\chi^{2}=210.4, \mathrm{df}=3, P<0.001 ; \chi^{2}=172.63$, df $=3$, $P<0.001 ; \quad \chi^{2}=142.02, \quad \mathrm{df}=3, \quad P<0.001 \quad$ and $\chi^{2}=144.18$, df $=3, P<0.001$ ) (Fig. 2). The efficacies of Bt broccoli plants on different $P$. rapae instars were consistently $\operatorname{cryl} l A c>\operatorname{cryl} A c+\operatorname{cry} l C>\operatorname{cry} l C$ with significant differences between them except between crylC and crylAc + crylC plants for the first $\left(\chi^{2}=0.22\right.$, df $\left.=1, P=0.637\right)$ and fourth instars $\left(\chi^{2}=0.22\right.$, df $\left.=1, P=0.638\right)$, and between crylAc and crylAc + crylC plants for fifth instars $\left(\chi^{2}=0.33\right.$, $\mathrm{df}=1, P=0.5634$ ).

\section{Impact on $\mathrm{P}$. rapae pupae}

Pupal length, width and weight were measured on P. rapae developed from fourth to fifth instars fed with different Bt broccoli plants for 1 and 2 days, respectively (Table 1). Pupal length was significantly affected by the instar being fed Bt broccoli plants or non-Bt plants $(F=8.808$, df $=3, P<0.001)$ and by feeding time on Bt plants $(F=8.766$, df $=1$, $P=0.006)$. Similarly, $P$. rapae pupal width was significantly affected by plant type (Bt/non-Bt) $(F=9.332$, df $=3, P<0.001)$ and feeding time $(F=13.521$, df $=1, P=0.001)$. Pupal weight was also significantly affected by plant type $(F=4.023$, df $=3, \quad P=0.016)$, but not by feeding time $(F=1.481$, df $=1, P=0.233)$. Important indicators of pupal quality, the length and the weight of $P$. rapae pupae, were both significantly reduced after the older larvae fed on either crylAc, crylC or crylAc + crylC broccoli plants for 2 days compared with their counterparts fed on non-Bt plants (Table 1).

Effects on parasitism, developmental time, proportion of females and longevity of Pteromalus puparum

Overall, the parasitism rate (\%) of $P$. puparum from the culture on $\mathrm{Bt}-\mathrm{fed}$ Pieris rapae pupae was lower
Fig. 2 Survival of $P$. rapae larvae after being fed with Bt broccoli plants and nonBt control plants from later instars until pupation. (A) Second instars, (B) third instars, (C) fourth instars, (D) fifth instars
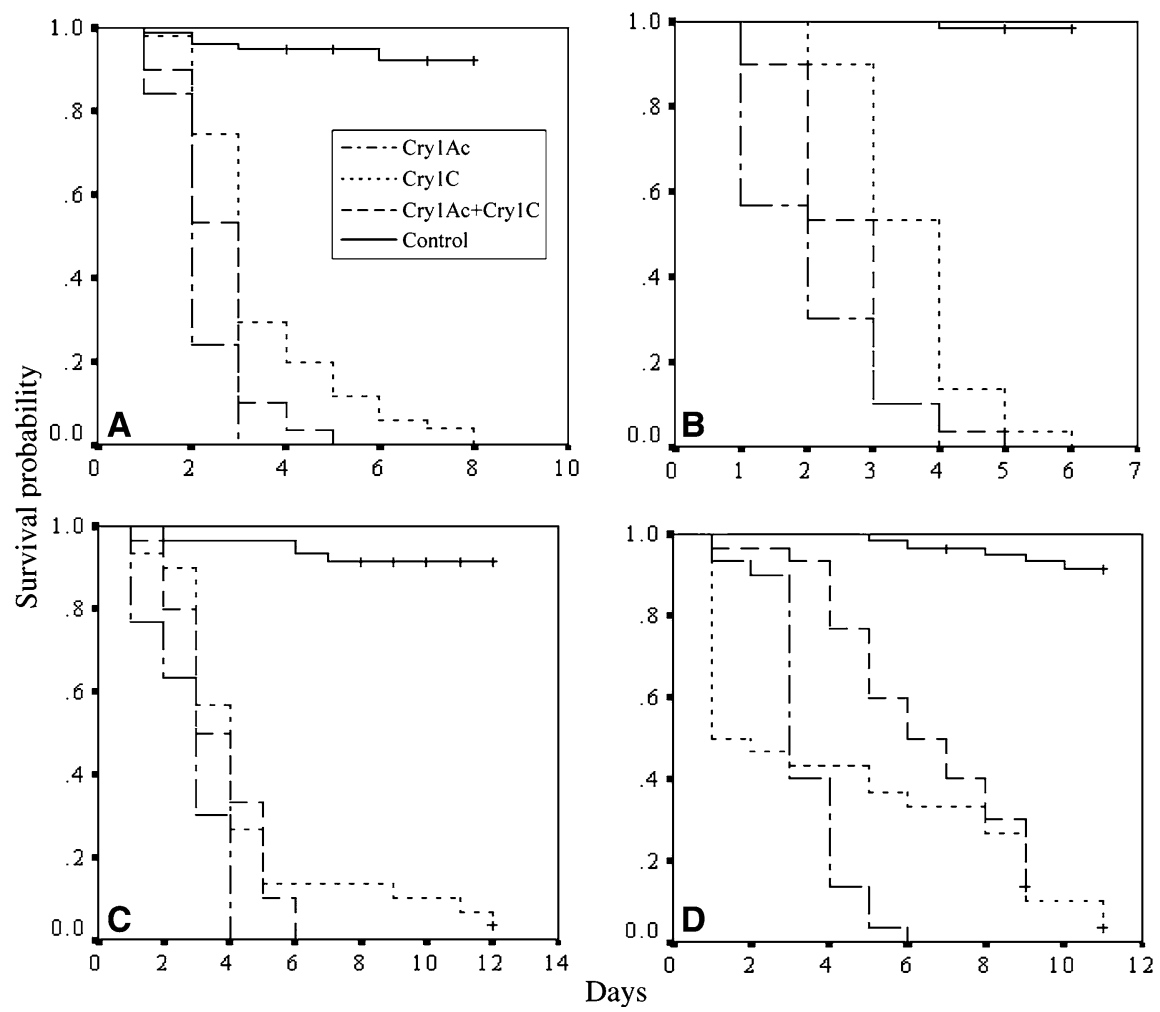
Table 1 Impact of different Bt broccoli plants on Pieris rapae pupal size after larvae had fed on Bacillus thuringiensis (Bt) and nonBt plants

\begin{tabular}{llllc}
\hline Plant type & Feeding time (days) & Length (mm) & Width (mm) & Weight (mg) \\
\hline crylAc & 1 & $17.1 \pm 0.3 \mathrm{a}$ & $4.3 \pm 0.2 \mathrm{a}$ & $106.8 \pm 3.0 \mathrm{a}$ \\
& 2 & $16.4 \pm 0.4^{*} \mathrm{a}$ & $4.0 \pm 0.2 \mathrm{a}$ & $99.2 \pm 4.7^{*} \mathrm{a}$ \\
crylC & 1 & $17.1 \pm 0.5 \mathrm{a}$ & $4.4 \pm 0.2 \mathrm{a}$ & $99.6 \pm 14.1 * \mathrm{a}$ \\
& 2 & $16.3 \pm 0.2^{*} \mathrm{a}$ & $4.1 \pm 0.1 \mathrm{a}$ & $89.0 \pm 3.8^{*} \mathrm{a}$ \\
crylAc + crylC & 1 & $17.2 \pm 0.2 \mathrm{a}$ & $4.6 \pm 0.1 \mathrm{a}$ & $110.1 \pm 5.0 \mathrm{a}$ \\
& 2 & $15.2 \pm 0.2 * \mathrm{~b}$ & $3.6 \pm 0.1^{*} \mathrm{~b}$ & $91.2 \pm 3.3^{*} \mathrm{a}$ \\
Control & & $18.1 \pm 0.2$ & $4.8 \pm 0.1$ & $129.7 \pm 18.5$ \\
\hline
\end{tabular}

Values are means \pm standard error. Those followed by an asterisk $(*)$ within a column are significantly different from the non-Bt control. Means from different feeding time treatments for the same plant type followed by different lowercase letters are significant different (two-way ANOVA and Fisher's protected LSD means separation test, $P<0.05$ )

than that on a non-Bt-fed host (Table 2). As the feeding time on Bt broccoli plants increased from 1 day to 2 day, the parasitism rate significantly decreased compared with the parasitism rate of non-Bt-fed $P$. rapae $(F=6.825$, df $=1, P=0.014)$, but no significant difference was found between plant types $(F=1.649, \mathrm{df}=3, P=0.198)$. Developmental time and total number of $P$. puparum emerging from $P$. rapae pupae were significantly affected by plant type $(F=5.747$, df $=3, P=0.003$ and $F=6.179$, $\mathrm{df}=3, P=0.002$, respectively), but not by feeding time $(F=0.001$, df $=1, P=0.980$ and $F=0.007$, df $=1, P=0.933$, respectively). The longevity of emerged $P$. puparum was significantly affected both by plant type $(F=64.727$, df $=3, P<0.001)$ and feeding time $(F=17.675$, df $=1, P<0.001)$. However, the proportion of females was not significantly affected by plant type $(F=1.493$, df $=3, P=0.235)$ except for feeding time $(F=4.981, \mathrm{df}=1, P=0.033)$.
Effects on the progeny of Pteromalus puparum developing from Bt broccoli-fed Pieris rapae

Pteromalus puparum adults developing from $\mathrm{Bt}$ broccoli-fed $P$. rapae pupae were negatively affected, as seen by the results above (Table 1). In order to assess whether this impact could be carried over to the next generation and affect subsequent host utilization, $P$. puparum adults developing from $\mathrm{Bt}$ plant-fed $P$. rapae were inoculated to conventional hosts (Table 3 ). The parasitism rate of $P$. puparum from different $\mathrm{Bt}$ treatments was not significantly impacted compared with the non-Bt control ( $F=0.197, \mathrm{df}=3, P=0.897)$. Developmental time, total number and longevity of $P$. puparum were also not significantly affected by Bt plants $(F=2.540$, df $=3, P=0.093, F=0.105$, df $=3, P=0.956$ and $F=1.484$, df $=3, P=0.257$, respectively). The proportion of females from crylAc + crylC plants

Table 2 Impact of Bt broccoli plants on the parasitoid Pteromalus puparum developing from Bt plant-fed Pieris rapae

\begin{tabular}{lllllll}
\hline Plant type & $\begin{array}{l}\text { Feeding } \\
\text { time (days) }\end{array}$ & Parasitism (\%) & $\begin{array}{l}\text { Developmental } \\
\text { time (days) }\end{array}$ & $\begin{array}{l}\text { Total number } \\
\text { of } P \text {. puparum }\end{array}$ & $\begin{array}{l}\text { Proportion } \\
\text { of females }(\%)\end{array}$ & $\begin{array}{l}\text { Longevity } \\
(\text { days })\end{array}$ \\
\hline cry1Ac & 1 & $80 \pm 8.9 \mathrm{a}$ & $13.8 \pm 0.3 \mathrm{a}$ & $51.3 \pm 3.0 \mathrm{a}$ & $47.9 \pm 2.2 \mathrm{~b}$ & $27.8 \pm 0.7^{*} \mathrm{a}$ \\
& 2 & $60 \pm 8.9 \mathrm{a}$ & $13.4 \pm 0.2 \mathrm{a}$ & $60.3 \pm 4.8 \mathrm{a}$ & $65.0 \pm 6.4 \mathrm{a}$ & $21.3 \pm 0.5^{*} \mathrm{~b}$ \\
cry1C & 1 & $76 \pm 7.5 \mathrm{a}$ & $15.6 \pm 0.5 \mathrm{a}$ & $53.1 \pm 4.5 \mathrm{a}$ & $50.4 \pm 2.1 \mathrm{a}$ & $38.1 \pm 0.8 \mathrm{a}$ \\
& 2 & $64 \pm 9.8 \mathrm{a}$ & $15.8 \pm 1.0^{*} \mathrm{a}$ & $54.1 \pm 5.8 \mathrm{a}$ & $56.5 \pm 5.3 \mathrm{a}$ & $32.6 \pm 1.5^{*} \mathrm{~b}$ \\
cry1Ac + cry1Ac & 1 & $80 \pm 6.3 \mathrm{a}$ & $14.7 \pm 0.1 \mathrm{a}$ & $48.4 \pm 2.0 \mathrm{a}$ & $59.7 \pm 2.1 \mathrm{a}$ & $25.8 \pm 1.4^{*} \mathrm{a}$ \\
& 2 & $48 \pm 10.2^{*} \mathrm{~b}$ & $15.0 \pm 0.8 \mathrm{a}$ & $37.3 \pm 2.4^{*} \mathrm{~b}$ & $65.4 \pm 7.8 \mathrm{a}$ & $20.1 \pm 1.6^{*} \mathrm{~b}$ \\
Control & & $84 \pm 4.0$ & $14.1 \pm 0.3$ & $60.1 \pm 4.6$ & $55.5 \pm 3.3$ & $40.6 \pm 2.2$ \\
\hline
\end{tabular}

Values are means ( \pm standard error. Those followed with an asterisk $(*)$ within a column are significantly different from the non-Bt control. Means from different feeding time treatments for the same plant type followed by different lower-case letters are significantly different (two-way ANOVA and Fisher's protected LSD means separation test, $P<0.05$ ) 
Table 3 Impact of Bt broccoli plants on the progeny of Pteromalus puparum developing from Bt plant-fed Pieris rapae

\begin{tabular}{llllll}
\hline Plant type & Parasitism (\%) & $\begin{array}{l}\text { Developmental } \\
\text { time (days) }\end{array}$ & $\begin{array}{l}\text { Total number } \\
\text { of P. puparum }\end{array}$ & $\begin{array}{l}\text { Proportion } \\
\text { of females (\%) }\end{array}$ & $\begin{array}{l}\text { Longevity } \\
(\text { days })\end{array}$ \\
\hline cry1Ac & $80 \pm 0 \mathrm{a}$ & $13.5 \pm 0.3 \mathrm{~b}$ & $56.4 \pm 2.9 \mathrm{a}$ & $53.2 \pm 1.7 \mathrm{a}, \mathrm{b}$ & $38.2 \pm 1.1 \mathrm{a}$ \\
cry1C & $76 \pm 9.8 \mathrm{a}$ & $14.3 \pm 0.1 \mathrm{a}$ & $57.7 \pm 3.1 \mathrm{a}$ & $54.6 \pm 2.3 \mathrm{a}, \mathrm{b}$ & $37.0 \pm 1.3 \mathrm{a}$ \\
cry1Ac + cry1C & $80 \pm 8.9 \mathrm{a}$ & $13.7 \pm 0.1 \mathrm{a}, \mathrm{b}$ & $58.3 \pm 3.9 \mathrm{a}$ & $36.6 \pm 3.7 \mathrm{~b}$ & $40.3 \pm 1.7 \mathrm{a}$ \\
Control & $84 \pm 4 \mathrm{a}$ & $14.1 \pm 0.3 \mathrm{a}, \mathrm{b}$ & $60.1 \pm 4.6 \mathrm{a}$ & $55.5 \pm 3.3 \mathrm{a}$ & $40.6 \pm 2.2 \mathrm{a}$ \\
\hline
\end{tabular}

Values are means \pm standard deviation. Those followed by different lower-case letters within a column are significantly different (one-way ANOVA and Fisher's protected LSD means separation test, $P<0.05$ )

was significantly lower than those from the non-Bt control $(F=10.012$, df $=3, P=0.001)$.
$(<1 \mathrm{ppb})$ of Cry1C protein was detected from $P$. puparum pupae.
Transfer of Cry1C toxin through different trophic levels

The stable expression of the crylC gene, with an average of $0.84 \mu \mathrm{g} / \mathrm{g}$ fresh weight was detected in crylC broccoli plants using ELISA. After fourth to fifth instar P. rapae larvae had fed upon Cry1C broccoli plants for 1 day, Cry1C toxin $(0.18 \pm 0.02 \mu \mathrm{g} / \mathrm{g}$ fresh weight) was detected in $P$. rapae pupae at a significantly lower level than that found in crylC broccoli plants $(F=35.587, \mathrm{df}=3, \quad P<0.001)$. After $P$. rapae had continuously fed on cry $1 C$ plants for 2 and 3 days, no further accumulation of Cry1C toxin was detected compared with the 1-day feeding (Fig. 3). No Cry1C toxin was detected from the parasitoid $P$. puparum adults developing from cry $1 C$ plant-fed $P$. rapae pupae; however, a trace amount

\section{Discussion}

Bt transgenic plants provide excellent control of several important lepidopteran pests of field crops. However, although many field studies to date have shown that $\mathrm{Bt}$ transgenic plants have a negligible impact on non-target organisms, including beneficials (Naranjo et al. 2005), a number of laboratory studies have shown negative effects (Ferry et al. 2003). As yet there are no clear international guidelines for assessing the effects of Bt plants with insecticidal protein on selected non-target arthropods. A tiered system adopted from the ecotoxicological evaluation of plant protection products is being suggested for such evaluation, and this approach includes a first tier of "worst-case" study under laboratory conditions
Fig. 3 Presence of Cry1C toxin in crylC broccoli plants, in Pieris rapae pupae developing from larvae that had fed on crylC broccoli plants for 1, 2 and 3 days and in its parasitoid Pteromalus puparum, as detected by ELISA. Means $( \pm \mathrm{SE})$ denoted with same lower-case letters are not significantly different (oneway ANOVA, $P<0.05$ )

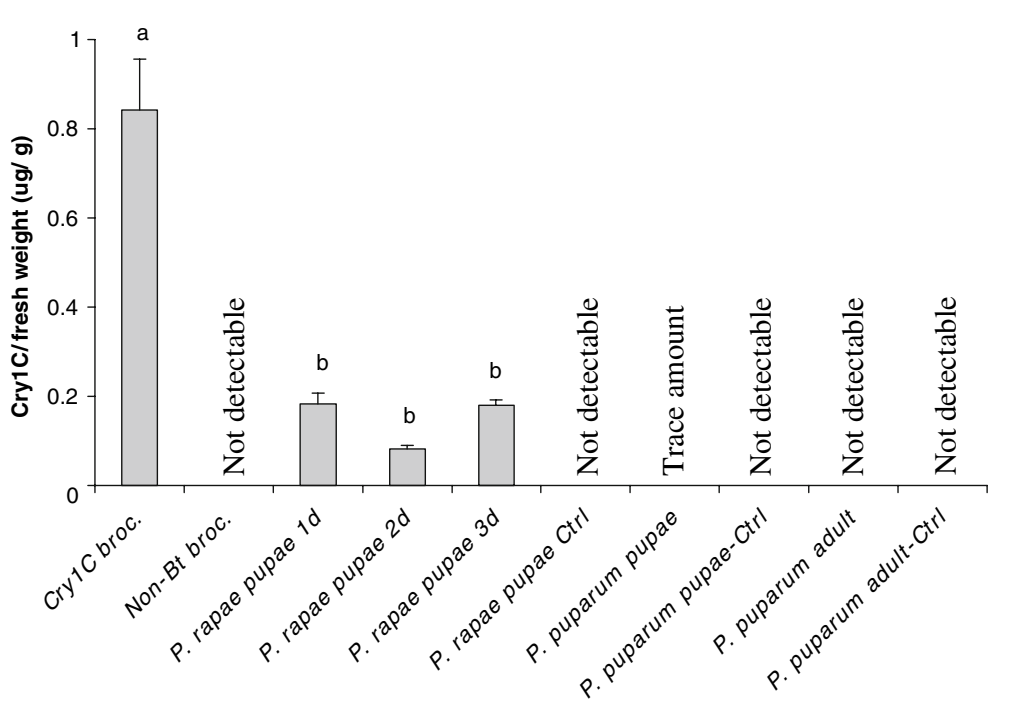


with additional studies if needed (Dutton et al. 2003; Poppy and Sutherland 2004; Rose 2006).

In the present "worst-case" study, we first evaluated the efficacy of the three types of Bt broccoli plants on different life-stage larvae of the herbivore Pieris rapae. The results indicated that single-gene Bt broccoli plants containing the crylAc or crylC gene effectively controlled $P$. rapae larvae. All first to third instars were killed by either single-gene or dual-gene $($ crylAc + crylC $)$ Bt broccoli plants (Figs. 1, 2). No $P$. rapae larvae was able to survive on crylAc broccoli for more than 6 days regardless of larval stage. Similarly, dual-gene broccoli plants also provided full control of the first to fourth instars, and only $3.33 \%$ of the fifth instars were able to survive. Our results with $P$. rapae are in line with the excellent efficacy of $\mathrm{Bt}$ broccoli plants against Plutella xylostella (Cao et al. 1999, 2002). Furthermore, our previous studies have shown that dual-gene broccoli plants can delay the evolution of $P$. xylostella resistance (Zhao et al. 2003, 2005), indicating that dual Bt gene broccoli plants should be considered for effective and sustainable control of lepidopteran pests on brassica vegetable crops.

Our studies on the impact of Bt broccoli plants on Pteromalus puparum, an endoparasitoid of $P$. rapae, indicated that $P$. puparum was significantly affected by $P$. rapae hosts that had fed upon Bt plants (Table 2). Parasitism rate, developmental time, total number and longevity of $P$. puparum were either significantly affected by plant type (Bt/non-Bt) or by feeding time on Bt plants. In one previous "worst-case" study, Vojtech et al. (2005) reported that the cocoons of the parasitoid Cotesia marginiventris (Hymenoptera: Braconidae) were smaller when developing in Spodoptera littoralis (Lepidoptera: Noctuidae) larvae that had fed on transgenic Bt maize. Also, the developmental times of $C$. marginiventris were longer than those developing in a non-Bt-fed host. However, the negative impact of $\mathrm{Bt}$ maize on $C$. marginiventris when developing in susceptible $S$. littoralis turned out to be indirect, i.e. host-mediated effects (Vojtech et al. 2005). Longer developmental time and reduced fecundity and longevity of parasitoids developing in or on Bt plant-fed hosts have also been reported in other studies (Bernal et al. 2002; Baur and Boethel 2003; Meissle et al. 2004). To date, however, we suggest that the mechanism of the negative impact of Bt plants on parasitoids is likely to be mediated by poor host quality. Our results indicate that the size (length and width) and weight of the host, $P$. rapae pupae developing from Bt broccolifed, were significantly affected compared with non-Bt plant-fed larvae. In addition, Bt toxin is known to change the amino acid and ion composition in the hemolymph of herbivores such as $S$. littoralis (Salama et al. 1983). This may suggest that less biomass and nutrition were available for $P$. puparum to complete development in Bt-treated hosts. In a recent study, Walker et al. (2007) evaluated the impact of Bt toxins on two larval parasitoids, Cotesia kazak Telenga (Hymenoptera: Braconidae) and Meteorus pulchricornis Wesmael (Hymenoptera: Braconidae), by feeding their herbivore hosts with diets amended with commercial preparations of Bt sprays and Cry1Ac toxin preparations. These researchers found that the larval development of both parasitoids was delayed only when there was a significant impact on the host. Reduced nutrition of hosts had a comparatively greater effect on parasitoid survival than Bt toxins (Walker et al. 2007). A number of earlier studies revealed that Bt-maize expressing the $c r y l A b$ gene caused negative effects on the predator Chrysoperla carnea Stephens (Neuroptera: Chrysopidae), i.e. higher mortality, prolonged development and a decrease in weight (Hilbeck et al. 1998a, b, 1999; Dutton et al. 2002). However, Romeis et al. (2004) fed high concentrations $(10,000$ times higher than that ingested when feeding on Bt-reared lepidopteran larvae) of Cry1 Ab toxin directly to $C$. carnea and found no direct toxic effect of the toxin on $C$. carnea larvae. Moreover, feeding first instar $C$. carnea with the Cry1Ab toxin did not affect the utilization of subsequently provided prey. Such direct studies are very appropriate and help to explain some spurious results with predators, but they are very difficult to perform with parasitoids whose survival relies on their host's survival.

Cry1C toxin was detected in the herbivore, $P$. rapae pupae, which meant that $P$. puparum were exposed to $\mathrm{Bt}$ toxin when they were parasitizing $P$. rapae pupae. Thus, direct effects of Bt toxin on the parasitoid cannot be ruled out, although it is very unlikely there would be a direct effect since $\mathrm{Bt}$ proteins need specific receptors in the target insect gut epithelium (Gill et al. 1992; Knowles 1994). To date, no direct effects on hymenopteran species have been demonstrated (Vojtech et al. 2005). Moreover, no Bt toxin was detected in newly emerged $P$. puparum adults, and only a trace amount of Bt toxin was 
detected in P. puparum pupae (Fig. 3). Foremost, these results suggest that $P$. puparum larvae did not take up Bt toxin. The trace amount of Bt toxin on $P$. puparum pupae is likely to be the result of tissues of $P$. rapae pupae clinging to the surfaces of the pupae because a trace amount of Bt toxin was also detected in the Wash Buffer that was used for washing the pupae before the ELISA tests (data not shown). Secondly, the Bt toxin, if ingested, may have been excreted or metabolized before the emergence of $P$. puparum adults from $P$. rapae pupae. Similar phenomena (toxin excretion and degradation) were reported in the predator Pirata subpiraticus Böesenberg et Strand (Araneae: Lycosidae) (Chen et al. 2005). In addition, our results indicate that parasitism rate, developmental time and longevity of the progeny of $P$. puparum developing from Bt broccoli-fed $P$. rapae were not significantly affected when inoculated with subsequently provided hosts (Table 3 ). Taken together, we conclude that Bt broccoli did not have an clear-cut direct effect on P. puparum.

Transgenic Bt vegetable brassicas are being considered as candidates for future release to farmers to control damage from lepidopteran pests (Srinivasan et al. 2005; Christey et al. 2006). Based on the results herein and those from our previous studies (Cao et al. 1999, 2002; Zhao et al. 2003), we conclude that such transgenic brassicas can be effective against a number of the more important Lepidoptera. We also conclude that, in the case of $P$. rapae, the negative impact of Bt broccoli on $P$. puparum resulted from poor quality of the host rather than direct effects of the Bt toxin and that this host quality-mediated impact did not adversely affect the progeny of $P$. puparum to utilize subsequently provided hosts. These results provide additional evidence that $\mathrm{Bt}$ plants can contribute to biological control within an overall integrated pest management program.

Acknowledgments We thank Yen Mei Cheung for assistance throughout this study and Hilda L. Collins for helpful comments on an earlier draft of the manuscript.

\section{References}

Baur ME, Boethel DJ (2003) Effect of Bt-cotton expressing Cry1Ac on the survival and fecundity of two hymenopteran parasitoids (Braconidae, Encyrtidae) in the laboratory. Biol Control 26:325-332
Bernal JS, Griset JG, Gillogly PO (2002) Impacts of developing on Bt maize-intoxicated hosts on fitness parameters of a stem borer parasitoid. J Entomol Sci 37:27-40

Bhattacharya RC, Viswakarma N, Bhat SR, Kirti PB, Chopra VL (2002) Development of insect-resistant cabbage plants expressing a synthetic crylAb gene from Bacillus thuringiensis. Curr Sci 83:146-150

Brookes G, Barfoot P (2006) Global impact of biotech cops: Socio-economic and environmental effects in the first ten years of commercial use. AgBioForum 9:139-151

Cao J, Shelton AM, Earle ED (2005) Development of transgenic collards (Brassica oleracea L., var. acephala) expressing a crylAc or crylC Bt gene for control of the diamondback moth. Crop Prot 24:804-813

Cao J, Tang JD, Strizhov N, Shelton AM, Earle ED (1999) Transgenic broccoli with high levels of Cry1C protein control diamondback moth larvae resistant to Cry1A or Cry1C. Mol Breed 5:131-141

Cao J, Zhao JZ, Tang JD, Shelton AM, Earle ED (2002) Broccoli plants with pyramided crylAc and crylC Bt genes control diamondback moth resistant to Cry1A and Cry1C proteins. Theor Appl Genet 105:258-264

Chen M, Ye GY, Lu XM, Hu C, Peng YF, Shu QY, Altosaar I (2005) Biotransfer and bioaccumulation of Cry1 Ab insecticidal protein in rice plant-brown planthopper-wolf spider food chain. Acta Entomol Sinica 48:208-213

Cho HS, Cao J, Ren JP, Earle ED (2001) Control of lepidopteran insect pests in transgenic Chinese cabbage (Brassica rapa ssp. pekinensis) transformed with a synthetic Bacillus thuringiensis crylC gene. Plant Cell Rep 20:1-7

Christey MC, Braun RH, Conner EL, Reader JK, White DWR, Voicey CR (2006) Cabbage white butterfly and diamondback moth resistant Brassica oleracea plants transgenic for Cry1Bal or cry1C. Acta Hortic 706:247-253

Dutton A, Klein H, Romeis J, Bigler F (2002) Uptake of Bttoxin by herbivores feeding on transgenic maize and consequences for the predator Chrysoperla carnea. Ecol Entomol 27:441-447

Dutton A, Romeis J, Bigler F (2003) Assessing the risks of insect resistant transgenic plants on entomophagous arthropods: Bt-maize expressing Cry1 $\mathrm{Ab}$ as a case study. BioControl 48:611-636

Ferry N, Edwards MG, Mulligan EA, Emami K, Petrova A, Frantescu M, Davison GM, Gatehouse AMR (2003) Engineering resistance to insect pests. In: Christou P, Klee H (eds) Handbook of plant biotechnology. John Wiley \& Sons, New York

Gill SS, Cowles EA, Pietrantonio PV (1992) The mode of action of Bacillus thuringiensis endotoxins. Annu Rev Entomol 37:615-636

Hilbeck A, Baumgartner M, Fried PM, Bigler F (1998a) Effects of transgenic Bacillus thuringiensis corn-fed prey on mortality and development time of immature Chrysoperla carnae (Neurophera: Chrysopidae). Environ Entomol 27:480-487

Hilbeck A, Moar WJ, Pusztai Carey M, Filippini A, Bigler F (1998b) Toxicity of Bacillus thuringiensis Cry1Ab toxin to the predator Chrysoperla carnae (Neurophera: Chrysopidae). Environ Entomol 27:1255-1263

Hilbeck A, Moar WJ, Pusztai Carey M, Filippini A, Bigler F (1999) Prey-mediated effects of Cry1Ab toxin and 
protoxin and Cry1A protoxin on the predator Chrysoperla carnae. Entomol Exp Appl 91:305-316

James C (2006) Global status of commercialized biotech/GM crops ISAAA Briefs, No. 35. ISAAA, Ithaca

Jin RG, Liu YB, Tabashnik BE, Borthakur D (2000) Development of transgenic cabbage (Brassica oleracea var. capitata) for insect resistance by Agrobacterium tumefaciens mediated transformation. In Vitro Cell Dev Biol 36:231-237

Knowles BH (1994) Mechanism of action of Bacillus thuringiensis insecticidal delta-endotoxins. Adv Insect Physiol 24:275-308

Mahr S (1996) Pteromalus puparum, parasite of imported cabbageworm. In: Midwest biological control new online. http://www.entomology.wisc.edu/mbcn/kyf312.html. Cited 7 Mar 2007

Meissle M, Vojtech E, Poppy GM (2004) Implications for the parasitoid Campoletis sonorensis (Hymenoptera: Ichneumonidae) when developing in Bt maize-fed Spodoptera littoralis larvae (Lepidoptera: Noctuidae). IOBC/WPRS Bull 27:117-123

Metz TD, Roush RT, Tang JD, Shelton AM, Earle ED (1995) Transgenic broccoli expressing a Bacillus thuringiensis insecticidal crystal protein: Implications for pest management strategies. Mol Breed 1:309-317

Naranjo SE, Head G, Dively GP (2005) Field studies assessing arthropod non-target effects in Bt transgenic crops: Introduction. Environ Entomol 34:1178-1180

Norusis M (2005) SPSS 13.0 advanced statistical procedure companion. Prentice Hall, Upper Saddle River

Poppy G, Sutherland JP (2004) Can biological control benefit from genetically-modified crops? Tritrophic interactions on insect-resistant transgenic plants. Physiol Entomol 29:259-268

Prütz G, Dettner K (2004) Effect of Bt corn leaf suspension on food consumption by Chilo partellus and life history parameters of its parasitoid Cotesia flavipes under laboratory conditions. Entomol Exp Appl 111:179-186

Romeis J, Dutton A, Bigler F (2004) Bacillus thuringiensis toxin $(\mathrm{Cry} 1 \mathrm{Ab})$ has no direct effect on larvae of the green lacewing Chrysoperla carnea (Stephens) (Neuroptera: Chrysopidae). J Insect Physiol 50:175-183

Romeis J, Meissle M, Bigler F (2006) Transgenic crops expressing Bacillus thuringiensis toxins and biological control. Nat Biotechnol 24:63-71

Rose RI (2006) Tier-based testing for effects of proteinaceous insecticidal plant-incorporated protectants on non-target arthropods in the context of regulatory risk assessment. IOBC/WPRS Bull 29:143-149

Salama HS, Zaki FN (1983) Interaction between Bacillus thuringiensis Berliner and the parasites and predators of Spodoptera littoralis in Egypt. Z Angew Entomol 95: 425-429

Salama HS, Sharaby A, Ragaei M (1983) Chemical changes in the haemolymph of Spidoptera littoralis (Lepidoptera: Noctuidae) as affected by Bacillus thuringiensis. Entomophaga 28:331-337

Schuler TH, Denholm I, Clark SJ, Stewart CN, Poppy GM (2004) Effects of Bt plants on the development and survival of the parasitoid Cotesia plutellae (Hymenoptera:
Braconidae) in susceptible and Bt-resistant larvae of the diamondback moth, Plutella xylostella (Lepidoptera: Plutellidae). J Insect Physiol 50:435-443

Shelton AM, Wilsey WT, Hoebeke ER, Schmaedick MA (2002a) Parasitoids of cabbage Lepidoptera in central New York. J Entomol Sci 37:270-271

Shelton AM, Wyman JA, Cushing NL, Apfelbeck K, Dennehy TJ, Mahr SER, Eigenbrode SD. (1993) Insecticide resistance of diamondback moth (Lepidoptra: Plutellidae) in North America. J Econ Entomol 86:11-19

Shelton AM, Zhao JZ, Roush RT (2002b) Economic, ecological, food safety, and social consequences of the deployment of $B t$ transgenic plants. Annu Rev Entomol 47:845-881

Srinivasan R, Talekar NS, Dhawan V (2005) Transgenic plants with dual $B t$ gene: An innovative initiative for sustainable management of Brassica insect pests. Curr Sci 88:18771879

Tang JD, Collins HL, Metz TD, Earle ED, Zhao JZ, Roush RT, Shelton AM (2001) Greenhouse tests on resistance management of Bt transgenic plants using refuge strategies. J Econ Entomol 94:240-247

US EPA (2001) Bt plant pesticides risk and benefit assessments. 2000 FIFRA SAP Rep. No. 200-07. http://www. epa. gov/scipoly/sap/2000/october/octoberfinal

Vásquez LA, Shelton AM, Hoffmann MP, Roush RT (1997) Laboratory evaluation of commercial trichogrammatid products for potential use against Plutella xylostella (L.) (Lepidoptera: Plutellidae). Biol Control 9:143-148

Vojtech E, Meissle M, Poppy GM (2005) Effects of Bt maize on the herbivore Spodoptera littoralis (Lepidoptera: Noctuidae) and the parasitoid Cotesia marginiventris (Hymenoptera: Braconidae). Transgenic Res 14:133-144

Walker GP, Cameron PJ, MacDonald FM, Madhusudhan VV, Wallace AR (2007) Impacts of Bacillus thuringiensis toxins on parasitoids (Hymenoptera: Braconidae) of Spodoptera littoralis and Helicoverpa armigera (Lepidoptera: Noctuidae). Biol Control 40:142-151

Webb SE, Shelton AM (1988) Laboratory rearing of the imported cabbageworm. New York Food Life Sci Bull 122:1-6

Wold-Burkness SJ, Hutchison WD, Lee JC, Hines RL, Bolin PC, Heimpel GE (2005) A long-term survey of parasitoid species composition and parasitism of Trichoplusia $n i$ (Lepidoptera: Noctuidae), Plutella xylostella (Lepidoptera: Plutellidae), and Pieris rapae (Lepidoptera: Pieridae) in Minnesota cabbage. J Entomol Sci 40:211-221

Zhao JZ, Cao J, Collins HL, Bates SL, Roush RT, Earle ED, Shelton AM (2005) Concurrent use of transgenic plants expressing a single and two Bacillus thuringiensis genes speeds insect adaptation to pyramided plants. Proc Natl Acad Sci USA 102:8426-8430

Zhao JZ, Cao J, Li YX, Collins HL, Roush RT, Earle ED, Shelton AM (2003) Transgenic plants expressing two Bacillus thuringiensis toxins delay insect resistance evolution. Nat Biotechnol 21:1493-1497

Zhao JZ, Li YX, Collins HL, Shelton AM (2002) Examination of the $\mathrm{F}_{2}$ screen for rare resistance alleles to Bacillus thuringiensis toxins in the diamondback moth. J Econ Entomol 95:14-21 